\title{
状態と決定の数が大きいマルコフ過程の 効率的な学習制御
}

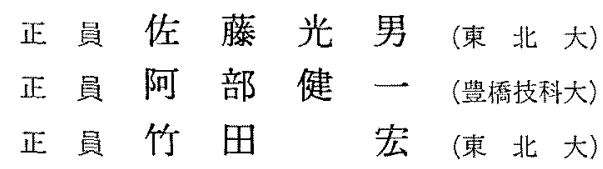

\section{1. まえがき}

未知パラメータを含む確率システムの学習制御モデ ルとして，Two-armed bandit問題，それを更に一般 化した Multiarmed bandit 問题，学猊オートマトン， および未知僄移確率の推定を伴うマルコフ決定問題な どがある(1)ー(10)。これらのうち，他のモデルをその特 殊ケースとして含むマルコフ決定モデルは㮔々の実際 的な問題に応用できるしとが知られているので，未知 迭移確率の推定を含むマルコフ決定問題は理論的な面 からだりでなく尧際的な面から見ても興味深いもので ある。ところで，てれらはいずれも学習の最終目標を

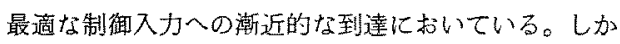
し，多くの場合，それを実現するのは非常に困難であ る。というのは，各制御入力が一力では推定のたかの 入力信号でああるととの結果として，末知パラメータ の推定とシステムの制御とが互いに矛盾する関係化す るからである。従って，いかにての矛盾を解決し，い か心巧妙に最適制御入力八の収束性を保証するかがこ れらに関する研究の主題となっている。

未知遷移確率の推定を伴うマルコフ決定問題に関 しては徒来上り種々の学翼方式の研究がなされてい

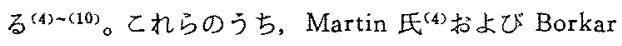
氏ら ${ }^{(5)}$ の示した力式は，最適制御入力への収束性を保 証するよいう意味では必ずし白最適でないととが判明 しているが(5)(13)，それ以外はいずれ屯独自の方法で推 定と制御の矛盾を解決し，上記の意昧での最適性を奏

\footnotetext{
Efficient Learning Control of Markov Chains with Many States and Decision. By Mitsuo Sato, Member (Tohoku University), Kenichi Abe, Member (Toyohashi University of Technology), \& Hiroshi Takeda, Member (Tohoku University).

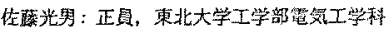

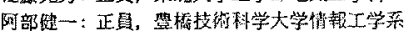

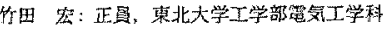

電学論 $\mathrm{C}, 107$ 巻 1 号, 昭 82
琴している。これら最適なもののうちEl-Fattah氏 ${ }^{(6)}$, Kumar 氏ら ${ }^{(7)}$ ，お上び著者ら ${ }^{(8)}$ の提案した方式は了 ルゴリズムの形が䄍雑であったり，尔るい，実際の 運用に当って匴上の大きな图難を伴う。これに悋し て文戴 (10)の方式ではこれらの難点がかなり改善され ている。この力式は $\varepsilon$ 最適性を澏たす文献(9)の方 式と同じ考えに基つくくもので，その特徽は制御性能と 推定精度をえれぞれ反映する二つの項からなる評価基 集を制御入力の選択のために導入したことにある。こ の評価基準が単純な形をなすことから，この方式の運 用上の諸操作汃従来の方式に比へてかなり簡単化され 召。

文裁 (9)あるいは文献(10)の力式でも，しかし，シ ステムの状態やしりうる決定の数が大きくなるにつれ て寒際の運用に伴う計算量加急速に增大する。従子 て，この上うな場合においては，Howard 氏いの政策 反復法に類するような何らか心勃率的な手法が必要と なるう。このような㓋点加ら，本諭文では，モデルの 規模が大きい場合に卆十分対処できるように文献 (9) あるいは(10)の方式を本来の制御性能を損わずに更に 簡単化した方式を構成する。この簡単化は評価基準を 政策区復法などの利用に適した形に改めることを意味 し，このことにより特にモデルの規模が大きい場合の 計算量が大幅に軽減さ机ることになる。本馀文ではま た，理諭的興味の観点から，この評価基準を用いる方 式が単に最道であるだけでなく、制御变数の值のとり 方によってと最適にすなるとと在証明する。

\section{2. 問題の記述}

本論文では Howard 氏 ごく葓本的なマルコフ決定モデルを报うのでまず， それについて跘明する。システムのとりうる状態が全 
部で $N$ 违りあるとし $(N<\infty)$ ，その状態の集合を $S=$ $\{1, \cdots, N\}$ で表す。各時刻 $t=0,1,2, \cdots \cdots$ どとにシス テムはある状態からある状態に確率的侸移し，その たびにある利得が得られる。ただし, 各状態 $に$ に対 して決定の集合 $\Gamma_{i}=\left\{1, \cdots, K_{i}\right\}$ が制り当てられてお り $\left(K_{i}<\infty\right)$ ，ての中から一つの決定を選点てとによ

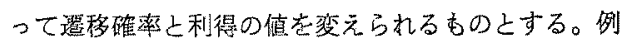
えばシステムが状態 $i$ にるときに決定 $k \in \Gamma_{i}$ を選 んだとすると，システムは時間に無関係な確率 $p_{i j}$ で状態 $j$ に遷移し $\left(p_{i j}{ }^{k} \geqq 0, \sum_{j=1}^{N} p_{i j^{k}=1}\right)$, それに伴

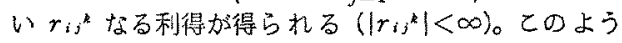
に決定を適当に選ふととによって僄移確率と利得の 值，をの結果として，利得の期待值を操作していく制

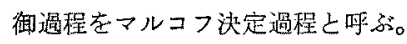

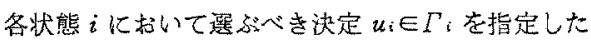
規則を政策己呵び，ここではこれを $N$ 次元べクトル $U=\left(u_{1}, \ldots, u_{N}\right)$ で表す。最適な制御入力として定義さ れているものの一つは今後得られるであるう総期待利 得を最大にするような政策である。ただし，将来の利 得についてはその価值を制り引いて考えるむのとし， 1 期間あたりの割引き率 $\beta$ を導入する $(0<\beta<1) 。 乙$ のような政策を $\beta$-最適政策と时手。初期状態を $i$ と して今後政策 $U$ を継続的に適用するときの総期待割 引き利得を $v_{i}{ }^{U}$ で表すと， $i \in S$ に関して一様に $v_{i}{ }^{U}$ を最大ならしめるUが存在する。これが $\beta$ 一最適政策 でこれを継続的に適用すれば常に将来の期待和得が 最大化される。 $v^{U}, \ldots, v_{N}^{U}$ は次の連立力程式のただ 1 組の有界な解で与えられる。

$$
v_{1}^{U}=\sum_{j} p_{i j}{ }^{u i} r_{i j}^{u i}+\beta \sum_{j} p_{i j}^{u i} v_{j}^{U}(i=1, \ldots, N)
$$

他の一つは過程の 1 期間むたりの平均期待利得を最大 ならしめる政策で，これは平均最適政策之㭔ばれる。 いま政策 $U$ を継絸的に適用する過程を考える。この 過程は定常マルコフ過程を形成するので，屯し過程が 正則ならば各状態 $i の$ 生起確率の極限傎 $\pi_{i}^{U}$ が存在 し，てれら注次の萧立方程式のただ1組の解で与えら れる(12)。

$$
\left.\begin{array}{l}
\pi_{j}^{U}=\sum_{i} \pi_{i}^{U} p_{i j} j^{u i} \quad(j=1, \ldots, N) \\
\sum_{i} \pi_{i}^{U}=1
\end{array}\right\}
$$

このとき $\theta^{U}=\sum_{i, j} \pi_{i}^{U} p_{i j^{i}}{ }^{i} \gamma_{i j}{ }^{u i}$ は過程の1期間あた りの平均期待利得を表す。 $g^{v}$ を最大ならしめるUか 平均鼠適政策である。

手し遥移確率 $p_{i j}^{*}$ の値がすべて既知ならば，上記 $v_{i}^{U} \odot g^{U}$ の值がすべて計算できるので $\beta$-最避政策や
平均最適政策を求めることができる。また，政策反复 法やその他の逐次近似法は必ずしすすべてのv゙ある いは $g^{U}$ の徝を計算するととなしに效率良く最適政策 を見い出すための手法である。しかしながら，本論文 での前提条件としていまはすへての翼移磼率 $p_{i j}{ }^{k} の$ 值を未和としているので，一般に最適な制御入力を求 めることはできない。そこで，このような条件下では 末知確率に関する推定情報をとり入れながら期待利得 が最適値に達するように制御していかなりればならな い。とのような行動形態を一種の学畾と言うととがで きる。

本論文では，各時刻で選択する政策が $\beta$-最適政策 あるいは平㚬最適政策に収束するような学習方式の構 成化つて論しる。なお，以下では，てれら2種類の 最適政策を特に区別はせずに単に最適政策 $U^{*}=\left(u_{1}^{*}\right.$, $\left.\ldots, u_{N}^{*}\right)$ として扱う。ここで議論の都合上次の仮定を おく。

【坂定1】すべての $k \in \Gamma i$ 执よび $i, j \in S$ に対し て $p_{i j}{ }^{k}>0$ である。

【仮定 2〕最適政策 $U^{*}$ はただ一つである。 仮定 2 は議論を簡潔にするための便宜的なすのであ るが，仮定 1はいかなる制御則のるとですすへての状 態が無限回生起することを保証するすので，これはす ベての透移確率を推定するのに必要である。また，仮 定 1 により，い加なる政策を継続的に適用しても過程 の正則性が満たされる。

\section{3. 推定と制御の矛盾}

前述のマルコフ決定過程において時刻 $t$ までの間に 状態 $i$ から決定 $k \in \Gamma ;$ の李と状態 $j$ に遷移した回 数を $n_{i j^{k}}(t)$ で表し, $n_{i}^{k}(t)=\sum_{j} n_{i j}{ }^{k}(t)$ および $n_{i}(t)=$ $\sum_{k} n_{i}^{k}(t)$ とする。乙のとき, 周知のように, $\hat{p}_{i j^{k}}(t)=$ $n_{i j}{ }^{k}(t) / n_{i}{ }^{k}(t)$ は要移酸率 $p_{i j}{ }^{k}$ の最尤推定值之なる。 iおよびk，をそれぞれ時刻 $t$ において生起した状態 およびそとで用いられだ決定上すると，てれらや上記 に定義した $n_{i j}{ }^{k}(t)$ などの諸量はいずれ状態選移の

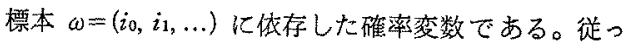
て，これらに関する記述はすべて与えられた確率空間 $(\Omega, \mathscr{F}, P)$ を基盤ししてなされる。ここに， $\Omega$ はすべ ての $\omega$ 加なる標本空間，正は $\Omega$ の部分集合加らな る $\sigma$-集合体，そしてPは適用される制御則のもとで

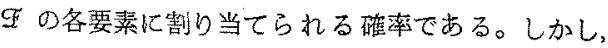
以下の確率的記述はいずれも確率1で成り立つととを 前提としているので，表示の簡単のためにそれらの記 述に战いて $\omega \rho, \mathscr{F} ， P$ を明示しない6の之する。 
さて, 推定值 $\hat{p}_{i j}{ }^{2}(t)$ の一致性に関して大数の強法則 加ら次の㭪題が導かれる。

【㭪題 1〕適用される制御則にかかわりなく $\lim _{t \rightarrow \infty}$ $n_{i}{ }^{*}(t)=\infty$ なるあらゆる $k \in \Gamma$ およよ゙ $i \in s に$ 対し て次式加成立する。

$$
\lim _{t \rightarrow \infty} \hat{p}_{i j}{ }^{k}(t)=p_{i j^{k}} \quad(j=1, \ldots, N)
$$

補題1の結果として，すへてて $k \in \Gamma$ および： に対して $p_{i j}$ を完全倠定するにはあらゆる状態 $i$ において $\Gamma$ 内内のらゆる決定を器限回用いなけ㣗ば ならない。ところが,一方, 制御本来の目的は各状態 iにおいて最遍な決定 $u_{i}^{*}$ のみを用いることにより達 成される。最適政策への収束とは推定を含む制御の最 適化により得られるものであるから，上記のように推

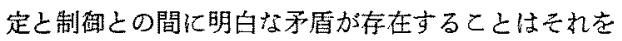
実現するうえでの大きな障害となる。

著者らはさきに，文献(9)求よび(10)に枋いて，推 定と制御の矛盾を陽に考虑した評価基集を政策選択の ために導入することによりその矛盾の解決を試みた。 この評価基準は制御性能を反映する項と推定精度を反

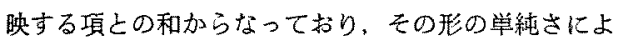
り学習方式の運用上の容易さが従来のものに比べてか なり改善されている。次章では，さきに導入した評碀 基準の制御に対応する項を更に簡単化することによ

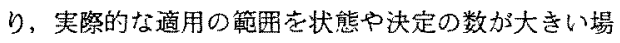
合にまで広げた方式を示す。

\section{4. 学習方式}

高べての $k \in \Gamma_{i}$ 占よひ $i, j \in s$ に対して $p_{i j}{ }^{k}=\hat{p}_{i j}{ }^{k}$

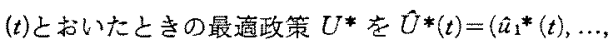

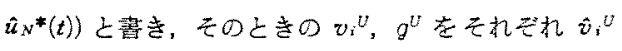
$(t), \hat{\theta}^{U}(t)$ と畫く。また，I をインジケー夕関数(事 象 $E$ 加真ならば $I(E)=1$, それが真でなければ $I(E)$ $=0$ なる関数）および $\alpha$ を任意の正定数とする。文献 (9)，(10)で導入された評価基準は制鹳に対応する項 こして $\hat{v}_{i}^{U}(t)$ を用いているが，乙れを実祭的により 簡等化された項 $\alpha I\left(U=\hat{U}^{*}(t)\right)$ で置意換えようという のがここでの提案である。すね古りここに提案する 学習方式とは，時刻 $t$ に部いて適用す心゙き政策加，之 のときのシステムの状態を $i$ とするとき，評洒基準

$$
w_{i}^{U}(t)=\alpha I\left(U=\hat{U}^{*}(t)\right)+\frac{c_{i}^{u i}(t)}{n_{i}^{u i}(t)}
$$

を最大ならしめるUで与えられるというあのである。 ここに $c_{i}^{* i}(t)$ は次に示すように逐次的に定如机る 奏数である（各 $i \in s$ に刘して $\left.c_{i}{ }^{u i}(0)=0\right) 。\{\theta(n)\}_{n=1}^{\infty}$ を $\sum_{n} \theta(n)=\infty$ なる正数列とする。ただし， $\theta(n)=\gamma$

電学論 C, 107 巻 1 号, 昭 62
(定数) あしくは $\lim _{n \rightarrow \infty} \theta(n)=0$ のどちらかである。い ま，時刻 $た$ にいて，ある政策が選ばれた結果として 決定 $d \in \Gamma$ ：か用いられたとする。このとき

$$
\left\{\begin{array}{rr}
c_{i}{ }^{u i}(t+1)=c_{i}{ }^{t i}(t)+\theta\left(n_{i}(t+1)-n_{i}{ }^{u i}(t+1)\right) \\
& \left(u_{i} \neq d\right) \\
c_{i}{ }^{d}(t+1)=c_{i}{ }^{d}(t) &
\end{array}\right.
$$

と定める。また，てのとき，すへてて $j \neq i(j \in s) に$ 对

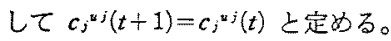

著者らがさきに提案した方式は $\theta(n)$ が定数ならは $\varepsilon$-最適の意昧で $\beta$-最適政策に到達し，また， $\lim _{n \rightarrow \infty}$ $\theta(n)=0$ ならば単にそれに到達することがそれでれ文 献 (9)，(10)で踶明されている。なお，てれらの証明 から明らかなことであるか，乙の方式において評価基 準の第1項として $\hat{v}_{i}{ }^{v}(t)$ の代りに $\hat{g}^{v}(t)$ を用いれば 平均最適政策への到達についても全く同嵄な結果が得 られる。評洒基睤の第 1 項としての $\hat{v}_{i}{ }^{U}(t) ， \hat{g}^{U}(t)$ ， あ るいは $\alpha I\left(U=U^{*}(t)\right) は$ ばれれ制御本来の目的に対 忘したあのである。というのは，この第 1 項だけが評 価基準しして与えられると，それによって選択される 政策が推定梿をすべて真值としたときの最遭政策とな るからである。一方，評洒基準の第 2 項は第 1 項の推

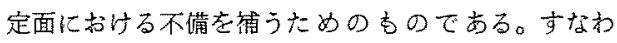
ち，乙の第 2 項は特定の未知確率の“推定の進子具合 い”あるいは“推定の连れ具合い”を数量化したもの でこれを評酒基準の中にとり入れることにより第 1 項だけ加らはもたらされない推定の促僬を区る四るので

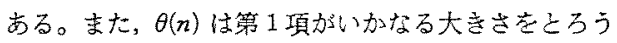
とも第 2 項をそれと程上く調和させるための制㑚变数 としての役割を持つ。徉って、ここに提案した方式で は，第 1 項に括ける定数 $\alpha$ の大さは方式の究極的な 特性には影㗽しない。ただし，その大きさは第 1 項と 第 2 項の初期の大小皆保化加かるので，収束の速度

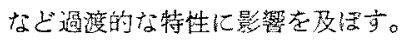

ところで，さきに提案した方式を実祭に運用すると き計算上手闎がかかるのは，評洒基染の算出に当っ

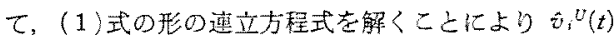
の值をすへての $U$ ，

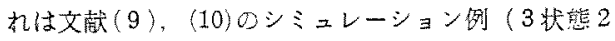
決定モデル) のように竝態や決定の数加小さい埸合に

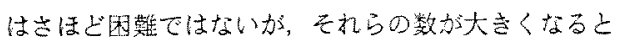
計算量のうえで非常に困難になる。この点とここに堤 案した方式では， $\hat{v}_{i}{ }^{\prime}(t)$ の缜を一ト求める必要はな く，その代りに推定值をすへて真焦ししたときの最䧟

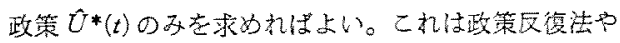
その他の逐次近以法の利用を可能にする毛ので，これ 
により評洒基䠋の算出が大幅に簡単化される。更に， $\hat{U}^{*}(t)$ を求めるのに政策反復法を用いるとき, 初期政 策として $O^{*}(t-1)$ を選ふならば，後に示すように $\lim _{t \rightarrow \infty} \hat{U}^{*}(t)=U^{*}$ であるこよから，tの増加につれても 計算上の負担汃大幅に軽減されることになるう。

\section{5. 漸 近特性}

以下では前章に提案した学说力式の湖近等性老決定 の使用频度を意味する係数 $f_{i}{ }^{k}(t)=n_{i}^{k}(t) / n_{i}(t)$ によ。 て調べる。まず $\theta(n)=\gamma$ のときの $\varepsilon$-最適性，次いで $\lim _{n \rightarrow \infty} \theta(n)=0$ の上きの最適性証明する。学漗方式の

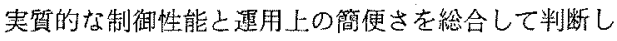
た場合には と一最適性と最適性上の差はほとんどない 上言える。しかし，理諭的な面加らみた場合，文献 (9)，(10)加ら击推察されるように最適性の証明は必 ずしもを最適性のそれを含まないのでこれらをて れぞれ学留方式の重要な性質として調べることにす る。ここで, 文献 (10)の補題 2 と同じ内容を持つ次の 補題を举げておく。

〔禣題 2〕仮定 1 のむとで，本方式は $\theta(n)=\gamma$ の きに屯 $\lim _{n \rightarrow \infty} \theta(n)=0$ のよきにもす心ての $k \in \Gamma i, i \in s$ に対して $\lim _{t \rightarrow \infty} n_{i}{ }^{k}(t)=\infty$ ならしぬる。

文裁 (10)の補題 2 の証明は，評洒基準の第 1 項につ

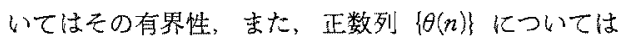
$\sum_{n} \theta(n)=\infty$ な性賴のみを用いてなされるので, 本方 式に関しても同じ補題が成り立つととは明らかであ る。

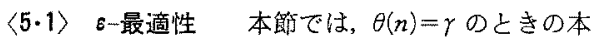
方式について，その $\varepsilon$-最適性を意昧する次の定理を 証明する。

【定理 1〕仮定 1 と纳定 20 あとて， $\theta(n)=\gamma$ のと きの本方式については次式が成立する。

$$
\lim _{\gamma \rightarrow 0} \lim _{t \rightarrow \infty} f_{i}{ }^{u} i *(t)=1 \quad(i=1, \ldots, N)
$$

仮定 1 よりどの状態む一様に無限回生起するので， 任意の一つの i ある。ここで以下の䓰明に㧊いては任意の 1 状態 $i$ を 避んでそれを固定する。また（2)式の政策 $U$ に関 する最大化は

$$
w_{i}^{k}(t) \triangleq \alpha I\left(k=\hat{u}_{i}^{*}(t)\right)+\frac{c_{i}{ }^{k}(t)}{n_{i}{ }^{k}(t)}
$$

の決定 $k \in \Gamma: に$ 関する最大化に置き換えられるので， 以下の証明においては(2)式より报いやすい(3)式定 評俩基準として用いる。補題 1 と補題 2 加 $\lim _{t \rightarrow \infty} \hat{U}^{*}$ $(t)=U^{*}$ 徒って $\lim _{t \rightarrow \infty} \hat{a}_{i} *(t)=u_{i}{ }^{*}$ 少得られるので,
れを(3)式に適用すると十分大きなすべての $t$ に対し て次式の成り立つことがわかる。

$$
w_{i}{ }^{k}(t)=\alpha I\left(k=u_{i}{ }^{*}\right)+\frac{c_{i}{ }^{k}(t)}{n_{i}{ }^{k}(t)} \quad\left(k=1, \ldots, K_{i}\right)
$$

ところて，少くとも一つの $k \in \Gamma$; K対して $n_{i}^{k}(t)=0$ ならば当然ての評価基染は遊用できないので, 初期の 間はこれ以外の基準によらなりればならない。この 初期操作を適用に行うととによりすべての $t$ および $k \in \Gamma_{i}$ K齐して

$$
c_{i}^{k}(t)=\theta(1)+\theta(2)+\ldots+\theta\left(n_{i}(t)-n_{i}^{k}(t)\right)
$$

ならしめることができる。

$\theta(n)=\gamma$ のをには, (5)式により $c_{i}{ }^{k}(t)=\gamma\left[n_{i}(t)-\right.$ $n^{k}(t)$ で゙あるから，てれを(4)式代入す代入ことに より次式を得る。

$$
\begin{array}{r}
w_{i}^{k}(t)=\alpha I\left(k=u_{i}^{*}\right)+\gamma \frac{1-f_{i}^{k}(t)}{f_{i}^{k}(t)} \\
\left(k=1, \ldots, K_{i}\right)
\end{array}
$$

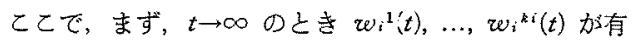
限な䛧に收束するという仮定を扣いてみる。すると明 らかにこ机らはすへて同じ収束値を持た极ばならない から，その值を $t \rightarrow \infty$ のとき $f_{i}^{k}(t)$ あ収束するので, その収束值を $\left.f_{i}{ }^{k} \neq 0\right)$ で表す上 $\left(k=1, \ldots, K_{i}\right) ，(6)$ 式上り

$$
w_{i}=\alpha I\left(k=u_{i}^{*}\right)+\gamma \frac{1-f_{i}{ }^{k}}{f_{i}{ }^{k}} \quad\left(k=1, \ldots, K_{i}\right)
$$

あるいは畵き換方て

$$
\begin{aligned}
f_{i}{ }^{k}=\gamma /\left(w_{i}-\alpha I\left(k=u_{i}{ }^{*}\right)+\gamma\right) \\
\left(k=1, \ldots, K_{i}\right) .
\end{aligned}
$$

を得る。(7)式により w> (8) 式志 $\sum_{k} f_{i}^{k}=1$ に代入するととにより，十分小さ な $\gamma$ のむで 根である確定值 $w^{*}$ で与えられるこよが導かれる。

$$
\begin{aligned}
& w_{i}^{2}-\left[\alpha+\left(K_{i}-2\right) \gamma\right] w_{i} \\
& +\gamma\left[\left(K_{i}-2\right)(\alpha-\gamma)-\gamma\right]=0 .
\end{aligned}
$$

そこで，次に， $t \rightarrow \infty$ の上き実際に $w_{i}^{1}(t), \ldots, w_{i}^{k^{k}}(t)$ がすべて い゙ に取束することを証明するために以下 の補題宗す。

〔禣題 3)级定 1 が成り立ち, $\theta(n)=y$ が-十分小さ いものとする。このとき, 十分大きな各 $t$ において, もしすべての $k \in \Gamma ; k$ 対して $w_{i}^{k}(t) \geqq w_{i}^{*}$ あるいは すべての $k \in \Gamma$ に対して $w_{i}^{*}(t) \leqq w^{*}$ ならばそれは すべての $k \in \Gamma_{i}$ に対して $w_{i}^{k}(t)=w_{i}^{*}$ であるこよを 意味する。 


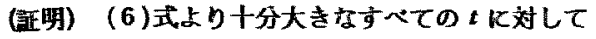

$$
\sum_{k} f_{i}^{k}(t)=\sum_{k} \frac{r}{w_{i}^{k}(t)-\alpha I\left(k=u_{i}^{*}\right)+\gamma}=1
$$

が成立方る。一方（9)式は(8)式を $\sum_{k} f_{i}^{k}=1$ K愔

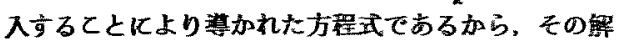
である $w^{*}$ *次式老湜する。

$$
\sum_{\boldsymbol{k}} \frac{r}{w_{i}^{*}-\alpha I\left(k-u_{i}^{*}\right)+\gamma}=1
$$

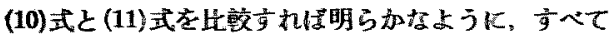

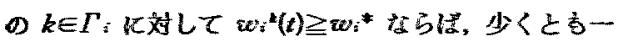

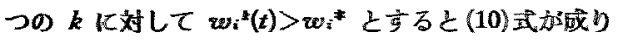
立たなくなる。てれら二つの不等号の间き样にして

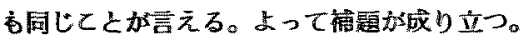

(設明督)

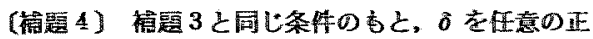

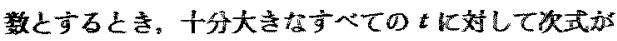
成立卞る。

$$
w_{i}{ }^{k}(t) \geqq w_{i}^{*}-\delta \quad\left(k=1, \ldots, K_{i}\right)
$$

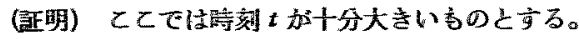

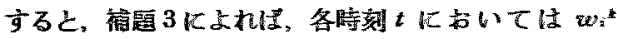
$(t)=w_{i}^{*}\left(k=1, \ldots, K_{i}\right)$ ᄒ $L<\notin \min _{k} w_{i}^{*}(t)<w_{i}^{*}<$

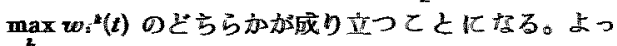

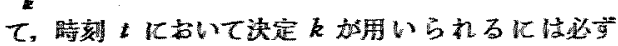

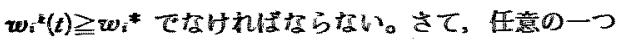

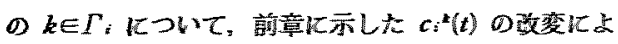
って(4)式大与去られる $w_{i}^{*}(t)=\alpha I\left(k=u_{i}^{*}\right) \div c_{i}^{*}(t) /$

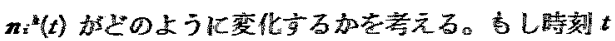

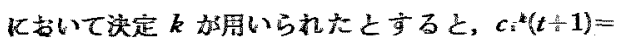

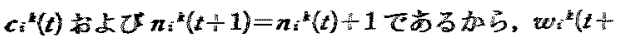

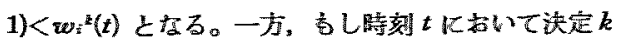

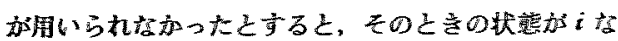

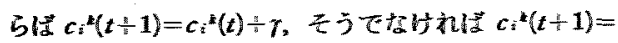

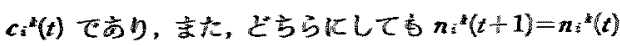

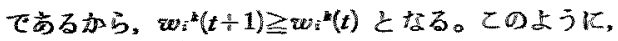

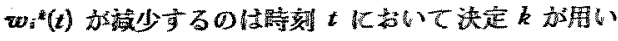
られたときだけでらる。

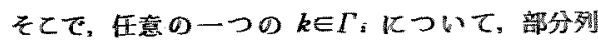

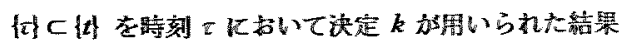

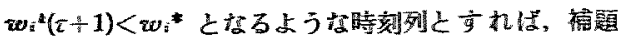

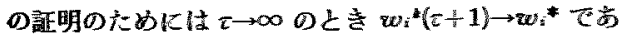
るととを示せばよい。ことで代繁限列であるこ

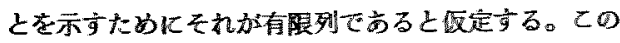

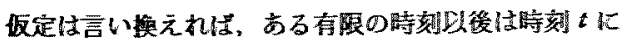

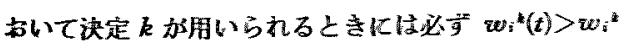

$(t \div 1) \geqq w^{*}$ こ㟔るというととになる。上記によりて

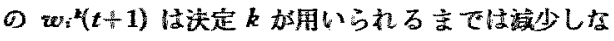

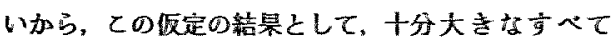

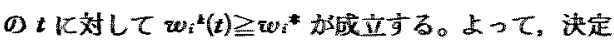

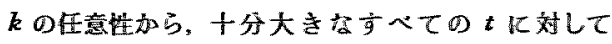

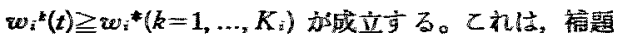

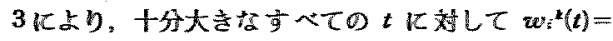

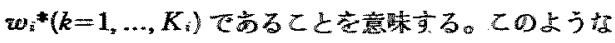

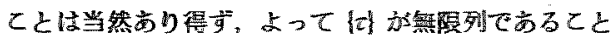

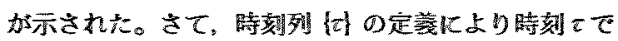

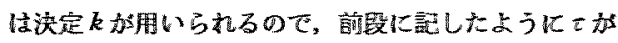

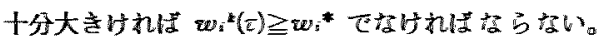
また，同定蒙化尗り $c_{i}^{*}\left(\tau \frac{*}{8} 1\right)=c_{i}^{*}(\tau), n_{i}^{*}(\tau+1)=n_{i}^{*}$

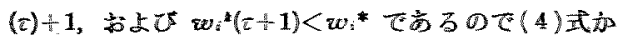

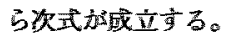

$$
\frac{c_{i}^{*}(\tau)}{n_{i}^{*}(\tau)+1}<w_{i}^{*}-\alpha I\left(k=u_{i}^{*}\right)<M
$$

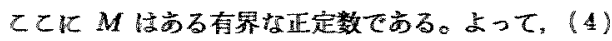
式放

$$
\begin{aligned}
& w_{i}^{*}(\tau)-w_{i}^{k}(\tau+1) \\
& =\frac{c_{i}^{*}(\tau)}{n_{i}^{*}(\tau)}-\frac{c_{i}^{*}(\tau)}{n_{i}^{*}(\tau)+1} \\
& =\frac{c_{i}^{*}(\tau)}{n_{i}^{*}(\tau)\left[n_{i}^{k}(\tau)+1\right]}<\frac{M}{n_{i}^{*}(\tau)}
\end{aligned}
$$

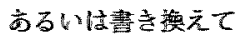

$$
w_{i}^{k}(\tau)-M / n_{i}^{k}(\tau)<w_{i}^{k}(\tau+1)
$$

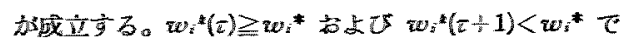

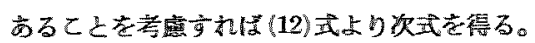

$$
w_{i}^{*}-M / n_{i}^{*}(\tau)<w_{i}^{*}(\varepsilon+1)<w_{i}^{*}
$$

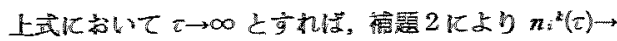

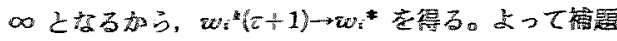
校証础された。

(武明終)

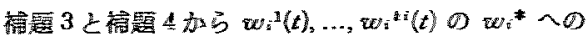

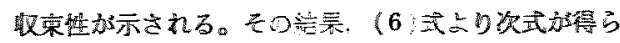
れる。

$$
\begin{aligned}
& \lim _{t \rightarrow \infty} f_{i}^{*}(t)=\frac{\gamma}{w_{i}^{*}-\alpha I\left(k=u_{i} *\right)+\gamma} \\
&\left(k=1, \ldots, K_{i}\right)
\end{aligned}
$$

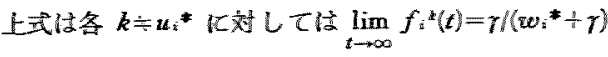

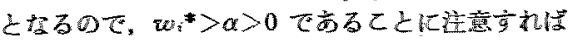

$$
\gamma \rightarrow 0 \text { OL要 } \lim _{t \rightarrow \infty} f_{i}^{*}(t) \rightarrow 0 \quad\left(k+u_{i}^{*}, k \in I_{i}\right)
$$

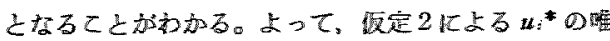

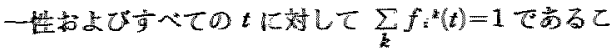

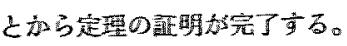

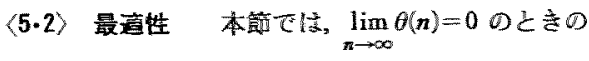


本方式について，その最適性を意味する次の定理を証 明ずる。

(定理 2)仮定 1 と仮定 20 もとで, $\lim _{n \rightarrow \infty} \theta(n)=00$ ときの本方式については $\lim _{t \rightarrow \infty} f_{i} i^{* *}(t)=1(i=1, \ldots, N)$ が成立する。

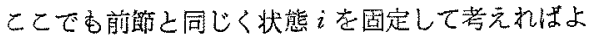
い。 $\bar{\theta}(n)=(1 / n) \sum_{m=1}^{n} \theta(m)$ とすると, (5)式の $c_{i}{ }^{k}(t)$ は

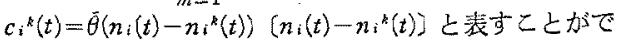
きるのので，これを(4)式に代入することにより次式を 得る。

$$
\begin{aligned}
& w_{i}^{k}(t)=\alpha I\left(k=u_{i}^{*}\right) \\
& +\bar{\theta}\left(n_{i}(t)-n_{i}^{k}(t)\right) \frac{1-f_{i}^{k}(t)}{f_{i}^{k}(t)} \\
& \quad\left(k=1, \ldots, K_{i}\right)
\end{aligned}
$$

徉って，十分大きなすへての $t$ 亿対して次式が成立す る。

$$
\begin{array}{r}
f_{i}{ }^{k}(t)=\frac{\bar{\theta}\left(n_{i}(t)-n_{i}{ }^{k}(t)\right)}{w_{i}{ }^{k}(t)+\bar{\theta}\left(n_{i}(t)-n_{i}{ }^{k}(t)\right)} \\
\left(k \neq u_{i}{ }^{*}, \quad k \in \Gamma_{i}\right)
\end{array}
$$

補題 2 乙 $\lim _{n \rightarrow \infty} \theta(n)=0$ 上り $\lim _{t \rightarrow \infty} \ddot{\theta}\left(n_{i}(t)-n_{i}{ }^{k}(t)\right)=0$ $\left(k=1, \ldots, K_{i}\right)$ が得られるので, 下記の䊇題が示され れば(13)式より

$$
\lim _{t \rightarrow \infty} f_{i}{ }^{k}(t)=0 \quad\left(k \neq u_{i}^{*}, k \in \Gamma_{i}\right)
$$

が得られ，よって，仮定 2 および $\sum_{k} f_{i}{ }^{k}(t)=1$ より定 理加導加れる。

〔補題 5〕仮定 1 のもとで，十分大きなす心゙てのt 比して $w_{i}^{*}(t)>\delta_{0}\left(k \neq u_{i}^{*}, k \in \Gamma_{i}\right)$ 上なるような $\delta 0>0$ が存在する。

(証明) 任意の一つの $k \neq u_{i}^{*}\left(k \in \Gamma_{i}\right)$ 肪用いら れる時刻列を $\left\{t_{i}\right\}_{i=1}^{\infty}$ で表すと，明らかに $w_{i}^{k}(t) \geqq$ $w_{i}^{a *}\left(t_{l}\right)$ であるので（4)式から十分大きなすべての $l$ に対して

$$
\begin{aligned}
w_{i}^{k}\left(t_{l}\right) & =c_{i}{ }^{k}\left(t_{l}\right) / n_{i}{ }^{k}\left(t_{l}\right) \geqq w_{i}^{u i *}\left(t_{l}\right) \\
& =\alpha+c_{i}^{u i *}\left(t_{l}\right) / n_{i}{ }^{u *}\left(t_{l}\right) \geqq \alpha
\end{aligned}
$$

また，更に

$$
\begin{aligned}
w_{i}{ }^{k}\left(t_{l}+1\right) & =c_{i}{ }^{k}\left(t_{l}+1\right) / n_{i}{ }^{k}\left(t_{l}+1\right) \\
& =\frac{c_{i}{ }^{k}\left(t_{l}\right)}{n_{i}{ }^{k}\left(t_{l}\right)+1}=\frac{n_{i}{ }^{k}\left(t_{l}\right)}{n_{i}{ }^{k}\left(t_{l}\right)+1} w_{i}{ }^{k}\left(t_{l}\right) \\
& \geqq \frac{n_{i}{ }^{k}\left(t_{l}\right)}{n_{i}{ }^{k}\left(t_{l}\right)+1} \alpha \quad \ldots \ldots \ldots \ldots . . .(15)
\end{aligned}
$$

荿立する。(14)式と(15)式より十分大きなすべての $l$ k対して $w_{i}^{k}\left(t_{l}\right)>\delta_{1}$ かつ $w_{i}^{k}\left(t_{t}+1\right)>\delta_{1}$ 上なるよ うな $\delta_{1}>0$ 加存在する。乙れは，十分大きな各 $t \neq t_{1}$ に対しては $w_{i}^{k}(t)=c_{i}^{k}(t) / n_{i}^{k}(t)$ 加隇少しないととか

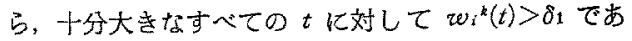
ることを意味する。従って, 決定の数が有限であるこ とから，榑題が成立する。

(証明終)

\section{6. シミュレーション例}

本方式の奏祭的な有效性を明らかにするために，文 献（9），(10)の方式にとっては適用ががり困難であ る5 状態 3 决定のモデルに本方式を適用した計算㙨シ ミュレーションの結果をことに示す。モデルの菤移確 率と利得はそれぞれ表 1 と表2のと扣りである。また 割引き率は $\beta=0.8$ である。この場合，政策の総数は

\section{表 1 遷移確率}

Table 1. Transition probabilities.

\begin{tabular}{lllll}
\hline$p_{11}^{1}=0.1$ & $p_{12}^{1}=0.2$ & $p_{13}^{1}=0.2$ & $p_{14}^{1}=0.2$ & $p_{15}^{1}=0.3$ \\
$p_{11}^{2}=0.2$ & $p_{12}^{2}=0.2$ & $p_{13}^{2}=0.2$ & $p_{14}^{2}=0.2$ & $p_{15}^{2}=0.2$ \\
$p_{11}^{3}=0.1$ & $p_{12}^{3}=0.1$ & $p_{13}^{3}=0.1$ & $p_{14}^{3}=0.3$ & $p_{15}^{3}=0.4$ \\
$p_{21}^{1}=0.1$ & $p_{22}^{1}=0.1$ & $p_{23}^{1}=0.2$ & $p_{24}^{1}=0.3$ & $p_{25}^{1}=0.3$ \\
$p_{21}^{2}=0.1$ & $p_{22}^{2}=0.1$ & $p_{23}^{2}=0.6$ & $p_{24}^{2}=0.1$ & $p_{25}^{2}=0.1$ \\
$p_{21}^{3}=0.1$ & $p_{22}^{3}=0.5$ & $p_{23}^{3}=0.2$ & $p_{24}^{3}=0.1$ & $p_{25}^{3}=0.1$ \\
$p_{31}^{1}=0.1$ & $p_{32}^{1}=0.4$ & $p_{33}^{1}=0.2$ & $p_{34}^{1}=0.2$ & $p_{35}^{1}=0.1$ \\
$p_{31}^{2}=0.3$ & $p_{32}^{2}=0.2$ & $p_{33}^{2}=0.2$ & $p_{34}^{2}=0.2$ & $p_{35}^{2}=0.1$ \\
$p_{31}^{3}=0.3$ & $p_{32}^{3}=0.2$ & $p_{33}^{3}=0.1$ & $p_{34}^{3}=0.1$ & $p_{35}^{3}=0.3$ \\
$p_{41}^{1}=0.2$ & $p_{42}^{1}=0.5$ & $p_{43}^{1}=0.1$ & $p_{44}^{1}=0.1$ & $p_{45}^{1}=0.1$ \\
$p_{41}^{2}=0.3$ & $p_{42}^{2}=0.1$ & $p_{43}^{2}=0.1$ & $p_{44}^{2}=0.4$ & $p_{45}^{2}=0.1$ \\
$p_{41}^{3}=0.2$ & $p_{42}^{3}=0.3$ & $p_{43}^{3}=0.3$ & $p_{44}^{3}=0.1$ & $p_{45}^{3}=0.1$ \\
$p_{51}^{1}=0.2$ & $p_{52}^{1}=0.2$ & $p_{53}^{1}=0.2$ & $p_{54}^{1}=0.2$ & $p_{55}^{1}=0.2$ \\
$p_{51}^{2}=0.2$ & $p_{52}^{2}=0.3$ & $p_{53}^{2}=0.2$ & $p_{54}^{2}=0.1$ & $p_{55}^{2}=0.2$ \\
$p_{51}^{3}=0.1$ & $p_{52}^{3}=0.4$ & $p_{53}^{3}=0.2$ & $p_{54}^{3}=0.1$ & $p_{55}^{3}=0.2$ \\
$p_{51}^{3}$ &
\end{tabular}

表 2 利得

Table 2. Rewards.

$\begin{array}{lllll}r_{11}^{1}=1 & r_{12}^{1}=-2 & r_{13}^{1}=-4 & r_{14}^{1}=-1 & r_{15}^{1}=3 \\ r_{11}^{2}=-2 & r_{12}^{2}=-7 & r_{13}^{2}=2 & r_{14}^{2}=8 & r_{15}^{2}=-1 \\ r_{11}^{3}=-3 & r_{12}^{3}=6 & r_{13}^{3}=-1 & r_{14}^{3}=-2 & r_{15}^{3}=4 \\ r_{21}^{1}=7 & r_{22}^{1}=-4 & r_{23}^{1}=1 & r_{24}^{1}=-2 & r_{25}^{1}=-3 \\ r_{21}^{2}=-5 & r_{22}^{2}=-2 & r_{23}^{2}=1 & r_{24}^{2}=-2 & r_{25}^{2}=5 \\ r_{21}^{3}=5 & r_{22}^{3}=-1 & r_{23}^{3}=-3 & r_{24}^{3}=-7 & r_{25}^{3}=0 \\ r_{31}^{1}=3 & r_{32}^{1}=1 & r_{33}^{1}=2 & r_{34}^{1}=4 & r_{35}^{1}=-4 \\ r_{31}^{2}=3 & r_{32}^{2}=0 & r_{33}^{2}=-1 & r_{34}^{2}=-3 & r_{35}^{2}=7 \\ r_{31}^{3}=-6 & r_{32}^{3}=1 & r_{33}^{3}=-2 & r_{34}^{3}=4 & r_{35}^{3}=0 \\ r_{41}^{1}=5 & r_{42}^{1}=-4 & r_{43}^{1}=3 & r_{44}^{1}=1 & r_{45}^{1}=-6 \\ r_{41}^{2}=3 & r_{42}^{2}=2 & r_{43}^{2}=-1 & r_{44}^{2}=-3 & r_{45}^{2}=-5 \\ r_{41}^{3}=4 & r_{42}^{3}=1 & r_{43}^{3}=-6 & r_{44}^{3}=6 & r_{45}^{3}=2 \\ r_{51}^{1}=2 & r_{52}^{1}=6 & r_{53}^{1}=2 & r_{54}^{1}=-1 & r_{55}^{1}=3 \\ r_{51}^{2}=-5 & r_{52}^{2}=1 & r_{53}^{2}=-3 & r_{54}^{2}=4 & r_{55}^{2}=-4 \\ r_{51}^{3}=-3 & r_{52}^{3}=5 & r_{53}^{3}=2 & r_{54}^{3}=-1 & r_{55}^{3}=-5 \\ 9\end{array}$




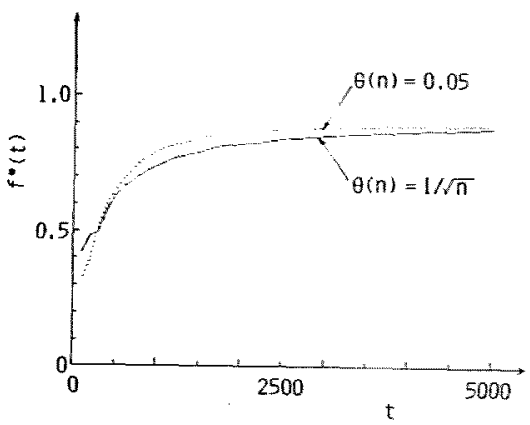

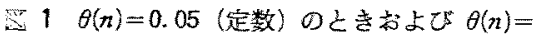
$1 / \sqrt{n}$ のときの $f^{*}(t)$ の $t$ 亿関主る变化

Fig. 1. Variations of $f^{*}(t)$ with respect to $t$ when $\theta(n)=0.05$ (constant) and when $\theta(n)=1 /$ $\sqrt{n}$.

$3^{5}=243$ であり，政策反復法などにより $\beta$-最䔔政策 $U^{*}=(3,2,1,3,1)$ 怔求的られる。従って，乙の場合，

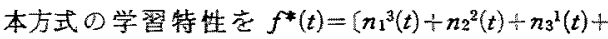
$\left.n 4^{3}(t)+n 5^{1}(t)\right) / t$ なる頝度係数の1への近つき方で表

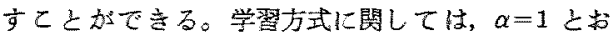
之, $\theta(n)\llcorner し \tau \theta(n)=0.05$ (定数) と $\theta(n)=1 / \sqrt{n} \omega$ 2とまりを考えた。

以上の条牪の苟とで実施されたシミュレーションの

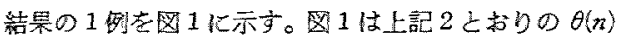
のあとでの $f^{*}(t)$ の $t$ 関する変化を表したすので ある。 3 状態 2 決定のモデルに対してす文献 $(10)$ と同 し条牪のもとで本方式を適用する計算栊シミュレー

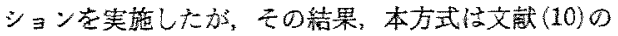

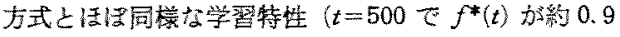
に到達りを示すことが礁認された。これらのシミュレ ーション繥果に上れで，状龍や決定の数が少し堷加し

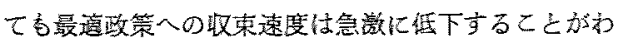

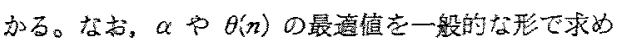

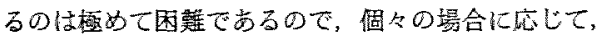
過去のシミニレーション例など香参芳にをれらを定め る必要加要る。

\section{7.むすび}

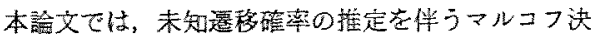

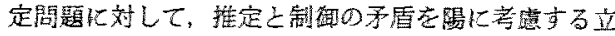
䭪加一つの学㥜方式を提案した。これはさきに著者

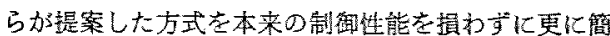

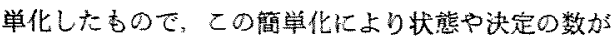

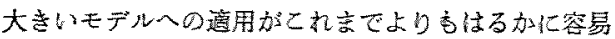
になる。更にまた，本方式は単に最远でるるだけでな

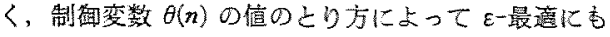
なることが証明された。

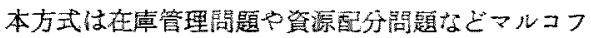

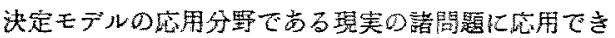

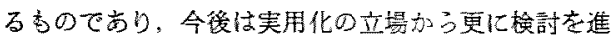
わていく必要加市。

(昭和 60 年10月25日受讨,同61年7月25日要受付)

\section{文献}

(1) I. H. Witten: "The Apparent Confict between Estimation and Control-A Survey of the Twomarmed Bandit Probm lem", J. Franklin Inst., 301, 161 (1976)

(2) P.P. Varaiya, J.C. Walrand, \& G. Buyukloc: "Exteasions of the Multiarmed Bandit Problem: The Discounted Case", IEEE Trans. Automatic Control, AC-30, 426 (1985)

(3) K.S. Narendra \& M. A.L. Thathachar: "Leaming AutomatarA Sury". IEEE Trans. Syst. Man Cybernetick SMC - 4, $323(1974)$

(4) J.J. Martin: Bayeaian Decision Problems and Markov Chains Wiley, 36 (1957)

(5) V. Botkat \& P. Varaiya: "Adaptive Control of Finite Markov Chains, I: Finite Parameter Set", IEEE Trans. Automatic Control, AC-24, 939 (1979)

(6) Y.M. El-Fatiah: "Recursive Algorithms for Adaptive Control of Finite Markov Chains", IEEE Trans. Syst. Man Cybernetics, SMC-11, 135 (1981)

(7) P.R. Kumar \& W. Lin: "Optimal Adaptive Controllers for Unknown Markov Chains", IEEE Trans. Automatic Control, AC-27,765 (1982)

(8) M. Sato, K. Abe, \& H. Takeda: "Learaing Control of Fisite Markov Chains wh Unknown Trassition Probabilities", IEEE Trans. Autonatic Controh, AC-27, 502 (1982)

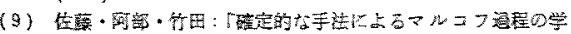

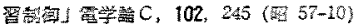

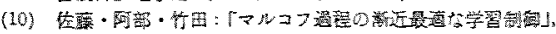

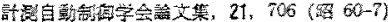

(11) R.A. Howard: Dynamic Programoing and Matkor Processes, MIT Press \& Whey, 32 (1900)

(12) J.G. Kemeny \& J.L. Snell: Finite Matrov Chains, D Van Nostrand Company, 69 (1900)

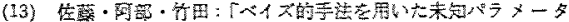

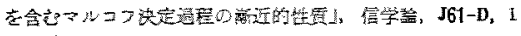
(阿 $53-1$ ) 